that these problems have a significant impact on the quality of current national legislation, as well as on their social effectiveness. Consequently, the quality of legal regulation is steadily decreasing, while the corruption and legal nihilism continue to grow in society.

This article uses empirical data obtained from domestic legislation to make some preliminary conclusions about the challenges peculiar for the institute of legal monitoring. The author argues this should be carried out in the areas of formalization and unification in the Law «On regulatory legal acts in Ukraine»; development of common approaches to the concept of further development of monitoring examinations (for example, regarding the need to single out the constitutionalization of existing legislation as a direction for the further analysis, constitutional monitoring and diagnostics of the certain constitutional processes); the inclusion in the subject structure of legal monitoring of all branches of governmental authorities, local governments, civil society, professional legal community, representatives of national jurisprudence, independent experts, etc.; ensuring prompt legal monitoring; provision of mandatory results to legal monitoring; the use of the latest information and communications technology necessary to create the official base of projects of regulatory legal acts, as well as the current legislation and practice of their implementation, the introduction of public (civil) legal monitoring and the creation of an Web-portal for its practical realization.

Key words: legal monitoring, legal expertise, effectiveness of legal regulation, quality of legislation, constitutionalization of legislation, civil society, public legal monitoring.

DOI: 10.33.66.3/2524-017X-2019-10-82-87

УДК 340.115

Ілля Дмитрович Шутак, професор кафедри теорії та історії держави і права Університету Короля Данила, доктор юридичних наук, професор, заслужений діяч науки і техніки Украйни

\title{
ПРАВОВИЙ МОНТТОРИНГ НОРМОТВОРЕННЯ, РЕАЛІЗАЦІЇ ТА ТЛУМАЧЕННЯ НОРМ ПРАВА В КОНТЕКСТІ ПРИНЦИПУ ВЕРХОВЕНСТВА ПРАВА
}

Постановка проблеми. Становлення нової правової системи в Україні відбувається досить складно, з розбіжностями. Негативною тенденцією в розвитку вітчизняного законодавства $\epsilon$ недостатня юридично-технічна опрацьованість актів законодавства, неналежне наукове обгрунтування правотворчих рішень, відсутність науково обгрунтованої технології законодавчого процесу.

Запровадження кожного законодавчого акта викликає у виконавців доволі різні почуття: від позитивного ставлення до необхідності роз'яснення деяких статей та пояснень щодо механізму практичного застосування окремих положень до негативного сприйняття його в цілому.

Нереалізованим досі залишається конституційне забезпечення пріоритетності законодавства. Головними причинами невиконання законів є: правовий нігілізм; помилкове праворозуміння; юридичні колізії між нормами права та нормативно-правовими актами (далі - НПА). Без дієвого механізму моніторингу ефективності НПА неможливо вчасно та якісно вирішити проблемні ситуації. Правовий моніторинг сприятиме досягненню ефективності чинного законодавства, відповідності його змісту сучасним вимогам розвитку держави та їі інститутів.

Аналіз останніх досліджень та пуб̆лікацій. Проблематику методології та методики оцінювання ефективності норм права у своїх наукових працях розкрили М. Шаргородський [4], А. Пашков та Л. Явич [5].

Загальнотеоретичні питання теорії держави та права, зокрема принципу верховенства права висвітлили М. Цвік, О. Петришин та Л. Авраменко [2].

Актуальні питання теорії та практики правового моніторингу досліджують зарубіжні вчені, зокрема М. Нарбінова [8], Ю. Тіхоміров [6], М. Турецький [7], Н. Черногора [3] та ін.

Однією з сучасних вітчизняних розробок, присвячених комплексному дослідженню правового моніторингу, є монографія I. I. Онищука. Автор розкрив організаційну, управлінську, інсти- 
туційну, функціональну та інструментальну складову сутності правового моніторингу. Запропоновано техніко-технологічний комплекс правил, методів та засобів здійснення послідовних операцій з метою контролю, аналізу, узагальнення, оцінювання якості та ефективності нормативно-правових актів і практики їх застосування, оформлення, оприлюднення та реалізації результатів моніторингу [1].

Мета дослідження - обгрунтувати доцільність конструювання та упровадження дієвого механізму моніторингу нормотворчості, реалізації та тлумачення норм права в контексті принципу верховенства права.

Основні результати дослідження. Принцип верховенства права висуває певні вимоги до текстів законів. Вираз «передбачене законом» означає ще й якість закону, тобто доступність для зацікавлених осіб внаслідок чіткості формулювання, щоб зацікавлені особи могли, отримавши за необхідності юридичну консультацію у справі, передбачати з розумним для даних умов рівнем визначеності ті наслідки, які може тягти за собою певна дія. Зазначені вимоги до якості законів Свропейський суд з прав людини доповнив більш широким за змістом міркуванням про те, що закон не повинен суперечити принципу верховенства права [1, с. 110].

Як зазначили М. В. Цвік, О. В. Петришин та Л. В. Авраменко, принцип верховенства права вимагає, щоб як мета діяльності держави, так і сама ця діяльність визначалися на основі правових рішень законодавців. Їх реалізація забезпечує незалежність державного апарату від зміни правлячих політичних сил, а також відносну безперервність розвитку держави. У правовій державі неприпустиме адміністративне свавілля, а тому доти, доки держава не буде реально обмежена правом, правовим законом, вона не може вважатися правовою [2, с. 513-514].

Одним з перших питань, що викликали широку наукову дискусію у зв'язку з розробкою методології вивчення ефективності законодавства, стало зміст поняття «ефективність норм права» («ефективність права»). У юридичній літературі радянського періоду висловлювалися різноманітні позиції. Зазначене поняття іноді повністю або частково ототожнювалося з оптимальністю, правильністю, обгрунтованістю, доцільністю самих норм права [3, с. 9].

Інформація про результати розглядається в якості істотного елементу державного управління суспільством. При цьому вчені не включали у зміст поняття «ефективність» обов'язковість наявності позитивного результату і його максимальний (оптимальний) ступінь, мотивуючи тим, що ефективність може бути негативною (зі знаком мінус) і виражатися в різному ступені (низькому, середньому, високому) [3, с. 10].

Близькою до зазначеної позиції була точка зору М. Шаргородського, що розглядав ефективність в якості абстрактного поняття, що означає здатність застосовуваних засобів сприяти досягненню бажаної мети [4, с. 54]. А. Пашков і Л. Явіч відзначали, що соціальна ефективність норми права передбачає досягнення об'єктивно необхідного і соціально корисного результату для будівництва комунізму [5, с. 42]. Д. М. Чечот потрактував ефективність правового регулювання як дієвість, результативність, здатність впливати на суспільні відносини у певному, корисному для суспільства напрямку [5, с. 3]. М. Лебедєвим висловлювалася думка, що ефективність правового впливу на суспільні відносини слід розуміти як отримання найкращого результату в досягненні мети даного правового припису і спільної мети [3, с. 12].

У сучасній правовій доктрині зароджується поняття правового моніторингу - систематичної, комплексної діяльності, спрямованої на спостереження, аналіз, оцінювання чинного законодавства та практики його застосування з метою підвищення ефективності законодавства та його подальшого прогнозування.

Правовий моніторинг - динамічний організаційний і правовий інститут інформаційно-оцінного характеру, що діє на всіх стадіях функціонування управління, господарювання та виявляється на всіх етапах виникнення і дії права [6, с. 13].

Правовий моніторинг - широке, багатопланове поняття, що охоплює кілька напрямків діяльності щодо забезпечення високої якості всіх процесів правового життя суспільства, при цьому в деяких країнах одночасно застосовуються різні його моделі [7, с. 216].

Правовий моніторинг - це основна ланка механізму реалізації правотворчої політики, яка використовує такі інструменти забезпечення високої якості нормативно-правових актів, як соціологічні дослідження, обробку та аналіз статистичних даних, прогнозування і моделювання дії майбутніх законів, комплексну експертизу законопроектів. Правовий моніторинг - це система безперервного 
Шутак І. Д. Правовий моніторинг нормотворення, реалізації та тлумачення норм права в контексті...

спостереження, аналізу і оцінки дії нормативно-правових актів з метою прогнозування подальшого розвитку законодавства і підвищення ефективності його регулювального впливу [8, с. 40].

Одним із завдань правового моніторингу є виявлення правових колізій: між сумісними загальними і спеціальними нормами, диспозиції яких співвідносяться як рід і вид; між загальними і спеціальними сумісними правовими нормами, диспозиції яких є різними і належать до одного роду; між принципами права та НПА; між загальними нормами права, при формулюванні яких використано слова «лише», «тільки», «виключно», «не інакше як», і спеціальними нормами права; між нормами права меншої юридичної та нормами права вищої юридичної сили; між нормами права та НПА, галузева належність яких не сходиться з галузевою належністю зазначених норм тощо [9, с. 22].

Розглянемо деякі приклади. В Основному Законі України чітко розрізняються випадки, коли певні винятки із загальних правил можуть встановлюватись тільки Конституцією (наприклад, ч. 1 ст. 64 КУ: «в умовах воєнного або надзвичайного стану можуть встановлюватися окремі обмеження прав і свобод із зазначенням строку дії цих обмежень»), і випадки, коли такі винятки можуть встановлюватись законом (наприклад, ст. 33 КУ). Передбачається також встановлення винятків із загальних конституційних норм Конституцією, міжнародними договорами України і законами (наприклад, ст. 26 КУ: «кожному, хто на законних підставах перебуває на території України, гарантується свобода пересування, вільний вибір місця проживання, право вільно залишати територію України, за винятком обмежень, які встановлюються законом»). 3 наведених випадків можна зробити висновок, що законодавчий орган уповноважений встановлювати винятки iз загальних конституційних норм. Такі норми-винятки застосовуються переважно перед конституційними нормами, до яких додається правове застереження про можливість встановлення законами норм винятків. До прикладу, норми винятки, розміщені в ст. 33; ч. 1 ст. 64 Конституції України, за юридичною силою прирівнюються до норм права та підлягають переважному застосуванню перед відповідними конституційними нормами. Наведене не порушує субординацію НПА та не може свідчити про перевагу правила «lex spesialis derogat generali» над правилом «lex superior derogat inferiori» [1, c. 79-80].

Проблема поділу норм права на текстуально закріплені і текстуально не закріплені (закріплені лише логічно) в актах законодавства, подальшого поділу цих двох родів норм права на види та виявлення особливостей кожного із цих видів норм права $є$ центральною проблемою теорії тлумачення НПА.

Тому уже тут на конкретному прикладі покажемо можливості використання методологічного інструментарію з метою виявлення норм права, які текстуально в актах законодавства не закріплені, але вмішуються в них логічно, і вирішення правових колізій між такими та іншими нормами права.

Згідно 3 пунктом 1 частини першої ст. 92 Конституції України виключно законами України визначаються «права і свободи людини і громадянина, гарантії цих прав і свобод; основні обов'язки громадянина». Наведене конституційне положення опрацьоване некоректно, оскільки надає діяльності держави спрямованості, що певною мірою є протилежною тій, яка закріплена у ст. 58 Конституції, йдеться про порядок доведення до відома населення не тільки законів, а й інших нормативно правових актів, що визначають права і обов'язки громадян. Натомість, згідно зі ст. 92 Конституції права людини і громадянина визначаються виключно законами.

У наведеному прикладі показано колізію між двома нормами права однакової юридичної сили (що виключає застосування правила про порядок вирішення ієрархічних колізій у законодавстві); однакову сферу дії (що виключає застосування для вирішення колізії правила про перевагу спеціальної правової норми), однакову здатність конкурувати при правозастосуванні.

Диспозиції норм права, про які йдеться, є несумісними. Логічних засобів вирішення таких колізій не існує. Вони повинні вирішуватись за допомогою принципу верховенства права, зокрема ст. 3 Конституції, що визначає спрямованість діяльності держави. Отже, права і свободи людини і громадянина, обов'язки громадянина можуть визначатись і законами, і підзаконними актами.

Основна проблема активного використання механізму правового моніторингу на практиці для визначення ефективності нормативно-правового регулювання та правозастосування полягає у відсутності опрацьованих і перевірених критеріїв, показників та методики оцінки останньої. Тому необхідно створити належні умови для проведення відповідного правового моніторингу. Моніторинг ефективності нормативно-правових актів шляхом послідовного аналізу всіх ланок цілісного процесу їх розробки, прийняття та реалізації дозволить виявити слабку ланку, регулю- 
вання або виключення якого слугуватиме підвищенню якості та ефективності нормативно-правових актів та законодавства в цілому [10, с. 147].

Як обгрунтував I. I. Онищук, з ціллю правового моніторингу як основний методичний прийом доцільно використовувати порівняльний аналіз структури проекту та структур близьких за характеристиками чинних НПА даної та споріднених галузей права. В якості прикладу неповноти структурної побудови наведено проект Закону України «Про первинну медичну допомогу на засадах сімейної медицини» (№ 6634 від 22.06 .2017 р.), де розділ IX містить тільки одну статтю. Однією з причин відхилення законопроектів «Про соціальну рекламу» (№ 8694 від 16.06.2011р.); «Про забезпечення доступу до надбань культури і мистецтва та протидіії їх комерціалізації» (№ 1052 від 12.12.2012 р.); «Про державний контроль над цінами на товари і послуги першої необхідності» (№ 10061 від 16.02.2012р.); «Про доступ до об’єктів будівництва, транспорту, електроенергетики 3 метою розвитку телекомунікаційних мереж» (№ 4159 від 26.02.2016р.) стало те, що законопроекти не мали самостійного предмета регулювання, а їх прийняття призвело б до правових колізій та дублювання норм чинного законодавства [9, с. 24].

Негативна тенденція посилення суперечностей між положеннями актів законодавства особливо проявилась у змісті Цивільного кодексу України і пов'язана із включенням до цього акта законодавства численних загальних і спеціальних положень, яких не було в раніше чинному Цивільному кодексі 1963 р. Так, до ч. 2 ст. 216 ЦК включене загальне положення, відповідно до якого «якщо у зв'язку із вчиненням недійсного правочину другій стороні або третій особі завдано збитків та моральної шкоди, вони підлягають відшкодуванню винною стороною». Щоб пояснити, як же співвідноситься це положення із спеціальними правилами про наслідки недійсності окремих видів правочинів, необхідно здійснити дуже складний аналіз з використанням методологічного інструментарію, яким ніхто не володіє. За наявності загальних правил про правові наслідки порушення зобов'язання (ст. 610625 ЦК) до цього Кодексу включаються численні спеціальні правила про наслідки порушення окремих видів зобов'язань - укласти основний договір на підставі попереднього договору (ч. 2 ст. 635 ЦК), передати проданий товар (ст. 665 ЦК), належне оплатити роботу, виконану за договором підряду (ст. 886 ЦК), здійснити платіж за чеком (ст. 1106 ЦК) тощо. Як співвідносяться згадані загальні та спеціальні правила, - це мала б пояснити методологія тлумачення актів законодавства. Особливо складно зрозуміти співвідношення ч. 3 ст. 1212 ЦК про наслідки набуття чи збереження майна без достатньої правової підстави 3 положеннями про повернення виконаного за недійсним правочином, витребування майна власником із чужого незаконного володіння, повернення виконаного однією із сторін у зобов'язанні, відшкодування шкоди особою, яка незаконно набула майно або зберегла його у себе за рахунок іншої особи [11, с. 16].

Варто звернути увагу ще й на оцінні поняття, які створюють передумови для індивідуального підходу до досліджуваних явищ та наукових суперечок. Серед оцінних понять, що використовуються у загальній частині Кримінального кодексу України, Ю. Хім'як виокремив такі, як «малозначність», «істотна шкода» (ч. 2 ст. 11), «необхідна і достатня шкода» (ч. 1 ст. 36), «тяжка шкода» (ч. 2 ст. 36), «тяжкі наслідки» (п. 5 ч. 1 ст. 67), «достатні підстави» (ч. 2 ст. 37), «явно злочинний наказ або розпорядження» (ч. 3 ст. 41), «значна суспільно корисна мета» (ч. 1 ст. 42), «тяжкі особисті, сімейні чи інші обставини» (п. 5 ч. 1 ст. 66), «аморальні дії» (п. 7 ч. 1 ст. 66), «істотно знижують ступінь тяжкості вчиненого злочину» (ч. 1 ст. 69) тощо [12, с. 66].

Адміністративне законодавство теж містить чимало оцінних понять. Узагальнивши положення чинного Кодексу України про адміністративні правопорушення, можна стверджувати про наявність понять, особливість яких полягає у вільному характері тлумачення. Виокремлюють «причини та умови, що сприяють вчиненню проступків» (ст. 6), «шкідливі наслідки» (ст. 11), «суспільні шкідливі посягання» (ст. 19), «хворобливий стан» (ст. 20), «доцільно» (ст. 21), «малозначності вчиненого» (ст. 22), «в дусі додержання законів» (ст. 23), «при збігу тяжких особистих чи сімейних обставин», «під впливом сильного душевного хвилювання» (ст. 34), «напіввільні умови» (ст. 881), «жорстоке поводження» (ст. 89), «інша шкода» (ст. 99), «грубе порушення» (ст. 108), «інший обман» (ст. 1552), «нецензурна лайка», «громадські місця», «образливе чіпляння», «спокій громадян» (ст. 173), «п'яний вигляд» (ст. 178), «злісна непокора» (ст. 1859), «неправомірна вигода» (ст. 21221), «своїм внутрішнім переконанням», «правосвідомістю» (ст. 252), «в можливо короткий строк» (ст. 259), «у виняткових випадках», «з особливою потребою» (ст. 263), «у невідкладних випадках» (ст. 264) тощо [13, с. 189]. 
Шутак І. Д. Правовий моніторинг нормотворення, реалізації та тлумачення норм права в контексті...

Під час тлумачення оцінні поняття набувають ознак формально-визначеного поняття [222, с. 76]. Вищі судові інституції під час узагальнення судової практики встановлюють орієнтир, здійснюючи перелік предметів, явищ, які замінені на оцінні поняття та закінчуються словами «та інші», «і т. д.», «тощо». Неповний перелік можна доповнювати та розширювати. Вищий адміністративний суд України у Рекомендаціях президії від 23 серпня 2007 року № 07.2 - 10/1 «Про деякі питання практики розгляду справ, пов'язаних з перерахунком пенсій деяким категоріям осіб публічної служби та науковим (науково-педагогічним) працівникам», роз'яснив, яку саме матеріальну допомогу не відносять до заробітку. Було зазначено, що, оскільки матеріальна допомога є одноразовою виплатою і не зазначена в переліку складових заробітної плати, передбачених ч. 2 ст. 33 Закону України «Про державну службу», то вона не включається до заробітку [14].

Судами формулюються визначення з використанням суджень, яким також притаманна абстрактність. До прикладу, у постанові Пленуму Вищого адміністративного суду України від 06 березня 2008 року № 2 «Про практику застосування адміністративними судами окремих положень Кодексу адміністративного судочинства України під час розгляду адміністративних справ», роз'яснюючи положення ч. 3 ст. 143 Кодексу адміністративного судочинства України щодо права вимоги особи виключити доказ, який на їі думку є фальшивим, Пленум вказав, що особа може здійснити висновок про підробку документа, якщо ознаки фальшування помітні неозброєним оком або така фальшивість переконливо підтверджена іншими доказами у справі [15].

Судами вживаються слова «а саме», «наприклад», «приміром». В Інформаційному листі Вищого адміністративного суду України від 24 грудня 2010 року № 1844/11/13-10 щодо питань, пов’язаних 3 оскарженням дій податкових органів про призначення позапланових перевірок платників податків та наказів про проведення таких перевірок, зазначено, що в разі очевидної наявності ознак протиправності наказу про призначення позапланової перевірки, адміністративні суди не позбавлені на підставі ч. 4 ст. 117 Кодексу адміністративного судочинства України права вжити заходів забезпечення позову у вигляді заборони вчиняти певні дії, а саме заборонити до вирішення спору по суті проведення відповідної перевірки [16].

Оцінні поняття мають низку специфічних властивостей, зокрема вони: фіксують лише найзагальніші ознаки відображених у них явищ $[17$, с. 6]; як правило, не конкретизуються і не роз'яснюються у правовій нормі законодавцем. (Така конкретизація у багатьох випадках може здійснюватися, зокрема, Пленумом Верховного Суду України в узагальненнях судової практики чи у постановах 3 конкретних справ); конкретизуються у процесі правозастосування у кожному конкретному випадку, створюють можливість індивідуального підходу до кожного суспільного відношення; дають можливість правозастосувальним органам «самостійно» оцінювати факти в межах, передбачених оцінною нормою, тобто створюють широкі можливості для власного угляду суб'єкта при реалізації та застосуванні їх на практиці; зумовлюють потребу їх уяснення і конкретизації з боку суб'єктів правовідносин, що значно розширює можливості правозастосовувачів (аж до суб'єктивізму включно); зміст оцінних понять та їхній об'єм можуть змінюватись у часі та залежати як від контексту норми, так і від особливостей конкретного випадку [18, с. 69].

Висновки. Вироблення практики регулярної оцінки стану національного законодавства сприятиме детальному осмисленню та аналізу можливих наслідків досягнення позитивних результатів у суспільстві, уникненню правових колізій та суперечностей, які періодично виникають у різних сферах суспільної діяльності.

До наявних передумов для створення та використання системи моніторингу законодавства можна зарахувати: досвід організації моніторингу за галузями законодавства; спеціалізовані (технічні) реєстри та бази даних; напрацювання центрів моніторингу права, громадських структур, спеціалізованих організацій.

3 метою формування та впровадження системи правового моніторингу в Україні необхідно визначити його стандарти, розробити та прийняти Закон України «Про правовий моніторинг», прийняти підзаконні нормативно-правові акти з метою конкретизації процедурних питань.

Юридичними параметрами правового моніторингу є чинні нормативні приписи Європейського суду з прав людини, Венеційської комісії, моніторингових органів Ради Європи, а також інші інституційні стандарти. У сфері правозастосовної практики доцільно використовувати інституційні стандарти, напрацьовані Європейською комісією з дієвості правосуддя (СЕРЕЈ) й Агенцією Європейського Союзу із засадничих прав (FRA). 
Крім того, процес вдосконалення правової системи України має включати в себе не тільки оцінку ефективності норм права, а й контроль, аналіз, узагальнення, оцінку якості нормативно-правових актів та практики їх застосування.

\section{Список використаних джерел}

1. Онищук I. I. Правовий моніторинг: проблеми методології, теорії та практики : моногр. / I. І. Онищук. - ІваноФранківськ - Дрогобич : Коло, 2017. - 512 с.

2. Загальна теорія держави і права: [Підручник для студентів юридичних вищих навчальних закладів] / М. В. Цвік, О. В. Петришин, Л. В. Авраменко та ін.; За ред. д-ра юрид. наук, проф., акад. АПрН України М. В. Цвіка, д-ра юрид. наук, проф., акад. АПрН України О. В. Петришина. - Харків : Право, 2009. - 584 с.

3. Правовой мониторинг : актуальные проблемы теории и практики / Под ред. Н. Н. Черногора. - М. : Международный юридический институт, 2010. - 232 с.

4. Шаргородский М. Д. Система наказаний и их эффективность / М. Д. Шаргородский // Советское государство и право. - М. : Наука, 1968. - № 11. - С. 53-61.

5. Пашков А. С., Явич Л. С. Эффективность действия правовой нормы (к методологии и методике социологического исследования) / А. С. Пашков, Л. С. Явич // Советское государство и право. - М. : Наука, 1970. № 3. - C. 40-47.

6. Тихомиров Ю. А. Организация и проведение правового мониторинга / Ю. А. Тихомиров // Право и экономика. - 2006. - № 10. - С. 11-15.

7. Турецкий Н. Н. Законодательная ветвь власти Казахстана : моногр. / Н. Н. Турецкий. - Алматы : ТОО «Издательство «Норма-К», 2011. - 356 с.

8. Нарбинова М. М. Мониторинг законодательства и правоприменительной практики как инновационный институт / М. М. Нарбинова // Государственное управление и государственная служба. - Астана, 2013. - С. 39-41

9. Онищук I. I. Моніторинг правових колізій і прогалин у законодавстві України / I. І. Онищук // Наукові записки Інституту законодавства Верховної Ради України, 2018 (6). - С. 21-26.

10. Онищук I. I. Поняття і види правового моніторингу / I. I. Онищук // Університетські наукові записки. Часопис Івано-Франківського університету права ім. Короля Данила Галицького. - Івано-Франківськ. - 2013. № 8. - C. 147-154.

11. Новітнє вчення про тлумачення правових актів : навч. посіб. з курсу тлумачення прав. актів для суддів, що проходять підвищ. кваліфікації, і канд. на посади суддів, що проходять спец. підготов. / В. Г. Ротань, І. Л. Самсін, А. Г. Ярема та ін. ; за ред. : В. Г. Ротань. - Х. : Право, 2013. - 752 с.

12. Хім'як Ю. Оціночні кримінально-правові поняття та вимога визначеності закону у рішеннях Європейського суду з прав людини / Ю. Хім’як // Вісник Нац. акад. прокур. України, 2011. - №2. - С. 65-70.

13. Костенко О. I. Проблеми тлумачення оцінних понять в адміністративному законодавстві України / О. I. Костенко // Вісник Запорізького національного університету, 2011. - № 1. - С. 187-193.

14. Про деякі питання практики розгляду справ, пов'язаних з перерахунком пенсій деяким категоріям осіб публічної служби та науковим (науково-педагогічним) працівникам : Рекомендації президії Вищого адміністративного суду України від 23 серпня 2007 року. URL: http://www.vasu.gov.ua/ua/generalization_court_practice. html?_m=publications\&_t=rec\&id=1548

15. Про практику застосування адміністративними судами окремих положень Кодексу адміністративного судочинства України під час розгляду адміністративних справ : постанова Пленуму Вищого адміністративного суду України від 6 березня 2008 року № 2. URL: http://zakon1.rada.gov.ua/cgibin/laws/main.cgi?nreg=v0002760-08. Назва. $з$ екрана.

16. Інформаційний лист Вищого адміністративного суду України від 24 грудня 2010 року № 1844/11/13-10. URL: http://www.vasu.gov.ua/ua/generalization_court_practice.html?_m=publications\&_t=r ec\&id=1686

17. Кашанина Т. В. Оценочные понятия в советском праве: автореф. дис. ... канд. юрид. наук.: 12.00 .01 / Кашанина Татьяна Васильевна; Свердловский юридический институт. - Свердловск, 1974. - 16 с.

18. Соловьева T. А. Оценочные понятия и суждения в уголовно-процессуальном праве / Т. А. Соловьева // Правоведение. - 1986. - №3. - С. 69.

\section{References}

1. Onyshchuk I. I. Pravovyj monitoryng: problemy metodologii', teorii' ta praktyky: monografija / I. I. Onyshchuk. Ivano-Frankivs'k - Drogobych: Kolo, 2017. - $512 \mathrm{s.}$

2. Zagal'na teorija derzhavy i prava: [Pidruchnyk dlja studentiv jurydychnyh vyshhyh navchal'nyh zakladiv] / M. V. Cvik, O. V. Petryshyn, L. V. Avramenko ta in.; Za red. d-ra juryd. nauk, prof., akad. APrN Ukrai’ny M. V. Cvika, d-ra juryd. nauk, prof., akad. APrN Ukrai'ny O. V. Petryshyna. - Harkiv: Pravo, 2009. - 584 s.

3. Pravovoj monitoring : aktual'nye problemy teorii i praktiki / Pod red. N. N. Chernogora. - M. : Mezhdunarodnyj juridicheskij institut, 2010. - $232 \mathrm{~s}$.

4. Shargorodskij M. D. Sistema nakazanij i ih jeffektivnost' / M. D. Shargorodskij // Sovetskoe gosudarstvo i pravo. M. : Nauka, 1968. - № 11. - S. 53-61. 
5. Pashkov A. S., Javich L. S. Jeffektivnost' dejstvija pravovoj normy (k metodologii i metodike sociologicheskogo issledovanija) / A. S. Pashkov, L. S. Javich // Sovetskoe gosudarstvo i pravo. - M. : Nauka, 1970. - № 3. - S. 40-47.

6. Tihomirov Ju. A. Organizacija i provedenie pravovogo monitoringa / Ju. A. Tihomirov // Pravo i jekonomika. 2006. - № 10. - S. 11-15.

7. Tureckij N. N. Zakonodatel'naja vetv' vlasti Kazahstana : Monografija / N. N. Tureckij. - Almaty : TOO «Izdatel'stvo «Norma-K», 2011. - $356 \mathrm{~s}$.

8. Narbinova M. M. Monitoring zakonodatel'stva i pravoprimenitel'noj praktiki kak innovacionnyj institut / M. M. Narbinova // Gosudarstvennoe upravlenie i gosudarstvennaja sluzhba. - Astana, 2013. - S. 39-41.

9. Onyshchuk I. I. Monitoryng pravovyh kolizij i progalyn u zakonodavstvi Ukrai'ny / I. I. Onyshhuk // Naukovi zapysky Instytutu zakonodavstva Verhovnoi’ Rady Ukrai’ny, 2018 (6). - S. 21-26.

10. Onyshchuk I. I. Ponjattja i vydy pravovogo monitoryngu / I. I. Onyshchuk // Universytets'ki naukovi zapysky. Chasopys Ivano-Frankivs'kogo universytetu prava im. Korolja Danyla Galyc'kogo. - Ivano-Frankivs'k. - 2013. № 8. - S. 147-154.

11. Novitnje vchennja pro tlumachennja pravovyh aktiv : navch. posib. z kursu tlu machennja prav. aktiv dlja suddiv, shho prohodjat' pidvyshh. kvalifikacii', i kand. na posady suddiv, shho prohodjat' spec. pidgotov. / V. G. Rotan', I. L. Samsin, A. G. Jarema ta in. ; za red. : V. G. Rotan'. - H. : Pravo, 2013. - 752 s.

12. Him 'jak Ju. Ocinochni kryminal'no-pravovi ponjattja ta vymoga vyznachenosti zakonu u rishennjah Jevropejs'kogo sudu z prav ljudyny / Ju. Him’jak // Visnyk Nac. akad. prokur. Ukrai’ny, 2011. - №2. - S. 65-70.

13. Kostenko O. I. Problemy tlumachennja ocinnyh ponjat'v administratyvnomu zakonodavstvi Ukrai'ny/O. I. Kostenko// Visnyk Zaporiz'kogo nacional'nogo universytetu, 2011. - № 1. - S. 187-193.

14. Pro dejaki pytannja praktyky rozgljadu sprav, pov'jazanyh $\mathrm{z}$ pererahunkom pensij dejakym kategorijam osib publichnoi' sluzhby ta naukovym (naukovo-pedagogichnym) pracivnykam : Rekomendacii' prezydii' Vyshhogo administratyvnogo sudu Ukrai'ny vid 23 serpnja 2007 roku. URL: http://www.vasu.gov.ua/ua/generalization_court_ practice.html? $\mathrm{m}=$ publications\&_t $=$ rec\&id $=1548$

15. Pro praktyku zastosuvannja administratyvnymy sudamy okremyh polozhen'Kodeksu administratyvnogo sudochynstva Ukrai'ny pid chas rozgljadu administratyvnyh sprav : Postanova Plenumu Vyshhogo administratyvnogo sudu Ukrai’ny vid 06 bereznja 2008 roku № 2. URL: http://zakon1.rada.gov.ua/cgibin/laws/main.cgi?nreg=v0002760-08. Nazva. z ekrana.

16. Informacijnyj lyst Vyshhogo administratyvnogo sudu Ukrai’ny vid 24 grudnja 2010 roku № 1844/11/13-10. URL: $\mathrm{http}: / /$ www.vasu.gov.ua/ua/generalization_court_practice.html?_m=publications\&_t $=\mathrm{r}$ ec\&id=1686

17. Kashanina T. V. Ocenochnye ponjatija v sovetskom prave: avtoref. dis. ... kand. jurid. nauk.: $12.00 .01 /$ Kashanina Tat'jana Vasil'evna; Sverdlovskij juridicheskij institut. - Sverdlovsk, 1974. - 16 s.

18. Solov'eva T. A. Ocenochnye ponjatija i suzhdenija v ugolovno-processual'nom prave / T. A. Solov'eva // Pravovedenie. - 1986. - №3. - S. 69.

\section{Шутак І. Д. Правовий моніторинг нормотворення, реалізації та тлумачення норм права в контексті принципу верховенства права}

Обгрунтовано доцільність конструювання та упровадження дієвого механізму моніторингу ефективності нормативно-правових в Україні шляхом визначення його стандартів, зокрема, розробкою та прийняттям Закону України «Про правовий моніторинг», прийняттям підзаконних нормативно-правових актів 3 метою конкретизації процедурних питань.

Розглянуто існуючі в науковій літературі погляди за ключовими теоретичними і прикладними проблемам у сфері здійснення правового моніторингу. 3'ясовано, що правовий моніторинг є інструментом динаміки права, який повинен супроводжувати всі елементи механізму правового регулювання: від формування нормативної бази до забезпечення законності й правопорядку.

Запропоновано вдосконалювати правову систему України оцінкою ефективності норм права, контролем, аналізом, узагальненням, моніторингом якості нормативно-правових актів та практики їх застосування, прогнозуванням напрямків розвитку правового регулювання суспільних відносин.

Ключові слова: правовий моніторинг, правове регулювання, правова експертиза, нормативно-правовий акт, правові колізії.

Shutak I. D. Legal monitoring of legal norms formation, implementation and interpretation in the context of the rule of law principal

The expediency of designing and implementing an effective mechanism for monitoring the effectiveness of legal and regulatory framework in Ukraine is substantiated by defining its standards, in particular, by developing and adopting the Law of Ukraine «On Legal Monitoring», adopting subordinate legal acts in order to specify procedural issues.

The existing scientific literature views on key theoretical and applied problems in the field of legal monitoring are considered. It was clarified that legal monitoring is an instrument of the dynamics of law, which must accompany all elements of the legal regulation mechanism: from the formation of the normative base to ensuring law and order. 
It is proposed to improve the legal system of Ukraine by assessing the effectiveness of the norms of law, control, analysis, generalization, monitoring of the quality of normative legal acts and practices of their application, forecasting directions of development of legal regulation of social relations.

Key words: legal monitoring, legal regulation, legal expertise, normative legal act, legal conflicts.

DOI: 10.33.66.3/2524-017X-2019-10-87-94

УДК 340

\begin{abstract}
Анатолій Свгенійович Шевченко, доктор юридичних наук, професор, професор кафедри теорії, історії права і держави та конституиійного права ННІП Університету державної фіскальної служби України
\end{abstract}

Алла Вікторівна Старостюк, кандидат юридичних наук, доиент, доцент кафедри теорії, історії права і держави та конституиіийного права ННІП

Університету державної фіскальної служби Украӥни

\section{ВІДРОДЖЕННЯ ДОВІРИ ДО ПРАВА ЯК ПОКАЗНИК ЕФЕКТИВНОСТІ ПРАВОВОГО МОНІТОРИНГУ}

Постановка проблеми. Сучасний етап розвитку України, який характеризується наявністю кризових явищ у багатьох сферах суспільного життя, потребує зосередження особливої уваги на питаннях відродження довіри до права як ефективного регулятора суспільних відносин. Варто зазначити, що ситуація, яка пов'язана із скептичним відношенням до права і недооціненням його можливостей в суспільній свідомості, виникла не миттєво. Вона $є$ наслідком існування багатьох трагічних сторінок нашої історії та довготривалого періоду нехтування цінностями права.

Виникає цілком закономірне питання: як могло статися, що такі фундаментальні цінності, як справедливість, свобода, відповідальність, довіра до права, досить важко закріплюються у якості основи формування поведінкових орієнтацій учасників суспільних відносин, а ситуація у сфері правотворчості, процесу забезпечення реалізації прав і свобод людини та громадянина в Україні набуває загрозливого характеру? Вважаємо, що однозначної відповіді на це запитання не знайдемо, оскільки вона залежить від аналізу цілого ряду чинників, які призвели до такого результату. Беззаперечним $\epsilon$ те, що в масовій суспільній свідомості міцно закріпили свої позиції правовий нігілізм, падіння довіри до правових інститутів, влади та її представників.

Аналіз останніх досліджень та публікацій. На теоретичному рівні розкриття сутності питань, які пов'язані з відродженням довіри до права, базовими $є$ наукові роботи, що стосуються проблем праворозуміння, дії права, функціонування та здійсненням державної влади. В зазначеному контексті спостерігаємо наявність вагомого внеску українських науковців щодо висвітлення зазначеної проблематики. Серед представників вітчизняної наукової еліти, які вивчали і продовжують брати активну участь в дослідженні цих питань, імена таких вчених, як С. Бобровник, Т. Дідич, А. Колодій, М. Козюбра, Н. Оніщенко, А. Селіванов, П. Рабінович, О. Тихоміров, В. Шаповал, Ю. Шемшученко та ін.

Мета статті - виявлення можливостей відродження довіри до права як результату ефективного процесу здійснення правового моніторингу.

Основні результати дослідження. Виходячи з розуміння того, що право - це мистецтво добра і справедливості (Ульпіан), відродження довіри до нього має розпочинатися з позицій забезпечення реалізації його ціннісних характеристик, саме з боку тих суб’єктів, діяльність яких пов'язана 3 процесом здійснення владних функцій, тобто представників державної влади. Варто пригадати думку А. Селіванова, який зазначав, що «рух країни до реального втілення в державне і суспільне життя цінностей права, побудови громадянського суспільства, панування правового закону і право- 